Bull. Fac. Agric., Cairo Univ.,58 (2007):212-216.

\title{
INFLUENCE OF WOODEN DIVERSITY ON INFESTATION LEVELS BY SUBTERRANEAN TERMITE Psammotermes hybostoma (DESNEUX) AT FAYOUM GOVERNORATE
}

(Received: 5.12.2006)

\author{
By \\ H.M.Ahmed \\ Plant Protection Research Institute, Agricultural Research Center, Dokki, Giza, Egypt.
}

\begin{abstract}
Throughout the field experiment tests, five species of local woods grown in Egypt; White mulberry, River oak, Sisso, Blue gum and Date palm trees and five species of imported wood species, European spruce, Mirbeck oak, Beech, Swedish pine and Mahogany were tested for their resistance or susceptibility to subterranean termite, Psammotermes hybostoma (Desneux) infestation. Except for River oak, Blue gum trees and Mahogany classified as durable woods, all other wood species exhibited varying degrees of subterranean termite infestation levels. Date palm and Beech were perishable and heavily infested with subterranean termite within short period (four months), and showed the highest damage and ratings.
\end{abstract}

Key words: damage ratings, imported woods, infestation, local woods, psammotermes hybostoma, resistance.

\section{INTRODUCTION}

Wood is becoming more and more scarce as a natural resource with increasing demand for its use in both building and industry. Subterranean termite species are considered one of the most important wood destroyers in the tropical and subtropical localities (Haverty \& Nutting 1975, Bultman et al., 1979, Badawi et al., 1985 and Delate \& Grace 1995). Subterranean termites are responsible for much of the degradation of woods and other cellulose materials in the terrestrial environment. Cellulose being the principal food of subterranean termite, wood and wood products such as paper, fabrics and wood structures are avidly consumed and destroyed by them, and hence, a constant effort is directed toward their control. Field studies indicated that, some wood species are susceptible but others are resistant to attack by subterranean termite (Abreu \& Silva 2000).Subterranean termites cause a great damage to wood in buildings, in storage and in use (Beal et al., 1974 and Grace et al., 1998). In Egypt, the damage is caused by subterranean termite species Psammotermes hybostoma (Desneux) to the rural buildings constructed with mud bricks as well as termite is considered an important pest of furniture and framed wood within buildings (Rizk et al., 1982 and Ahmed, 1997). This insect pest is a wide spread destructive to the local and imported wood species in Fayoum Governorate. Information are not available about the resistance or susceptibility of the local and imported wood species against subterranean termite, $P$. hybostoma infestation in Egypt, specially at Fayoum Governorate. Therefore the aim of this work was to study the influence of wooden diversity (local and imported wood species) on subterranean termite, $P$. hybostoma infestation levels.

\section{MATERIALS AND METHODS}

The experiments were conducted in Kasr AlGebaly location, Youssef El- Sediek district, at Fayoum Governorate from Jan. 2004 to Jan.2005. Two heavy infested locations by sand subterranean termite, Psammotermes hybostoma (Desneux) and two uninfested locations were chosen as control. The $1^{s t}$ location was $15 \times 10 \mathrm{~m}$., while the $2^{\text {nd }}$ one was $15 \mathrm{x} 12 \mathrm{~m}$. All superficial and partially buried of dead and debris woods were removed from these areas to prevent any nutrient interferences with the applied wood species .The soil was straighted and irrigated then left to full dry. For every location, 150 holes were digged with small axe, where; the holes were arranged in 10 rows (each row contains 15 holes). The distance between holes was one meter and the hole depth was $20 \mathrm{~cm}$. Thirty wooden stakes (40 $\mathrm{cm}$ length) from all tested wood species were obtained from wood atelier at Fayoum Governorate. Five local wood species, White 
mulberry (Morus alba L.), River oak (Casuarina equistifolia Mig), Sisso (Dalbergia sisso Roxb), Blue gum (Eucalyptus rostrata Schlechy) and Date palm(Phoenix dactylifera L.) and five imported wood species, European spruce (Picea sp.), Mirbecks oak (Quercus mibekii Dur.), Beech (Fagus sp.), Swedish pine (Pinus sp.) and Mahogany (Khaya sp. Desr.) were used in the present study. Wooden stakes were distributed randomly (each row contains three stakes per wood species) and fixed in the holes, where $20 \mathrm{~cm}$ was above the soil surface. Four months after initiating these experiments, the wooden stakes were pulled out and examined three times (10 wooden stakes per species per times) throughout the year of study on May, Sept. and Jan. The infestation levels were arranged according to Beal (1979) as follows:

(0) No attack (- )

(1) Little damage (+)

(2) Little damage with termite penetrate $(++)$

(3) Medium damage with termite penetrate $(++$ $+)$

(4) Heavy damage with termite penetrate $(++$ ++ )

(5) Completely damage $(+++++)$

Statistical analysis of the obtained data were carried out using analysis of variance ANOVA.

\section{RESULTS AND DISCUSSION}

\subsection{Local wood species}

Data in Table (1) show that, the wood of date palm tree (Phoenix dactylifera L.) was the most susceptible to insect infestation of the tested wooden stakes; followed by the wood of white mulberry (Morus alba L.) while wood species of Sisso tree(Dalbergia sisso Roxb) was the lowest susceptible to insect infestation. River oak wood (Casuarina equsitifolia Mig.) and the wood of Blue gum tree (Eucalyptus rostorata Schelchy) showed durable resistance to the subterranean termite $P$. hybostoma infestation. The mean numbers of the previous mentioned wood species were significantly different which were $7.33,6.00$, 1.67, 0.00 and 0.00 (stakes per 30 stakes) for Date palm, White mulberry, Sisso, River oak and Blue gum wood species, respectively. The corresponding rate of damage for these wood species were $2.2,1.2,0.23,0.00$ and 0.00 , respectively. These results revealed that, the two wood species River oak (Casuarina equsitifolia Mig.) and Blue gum (Eucalyptus rostorata Schelchy) were highly resistance to the subterranean termite $P$. hybostoma infestation where, no record of any infested wood stakes during the three inspections. Sisso trees (Dalbergia sisso Roxb) wood stakes were relatively resistance to $P$. hybostoma infestation where, only five wooden stakes were infested during the three inspections. Date palm and white mulberry woods were perishable. Therefore, tested wood species could be arranged according to their resistance to subterranean termite $P$. hybostoma infestation as follows: River oak (Casuarina equstifolia Mig.), Blue gum trees (Eucalyptus rostorata Schelchy), Sisso trees (Dalbergia sisso Roxb), White mulberry (Morus alba L.) and Date palm trees (Phoenix dactylifera $\mathrm{L}$. ),

respectively. These obtained results are in agreement with that of Rizk et al.,1982. They found that, the wood species Blue gum trees(Eucalyptus rostorata Schelchy), and River oak (Casuarina equstifolia Mig.), were the lowest preferable wood for subterranean termite Amitermes desertorum (Desneux).In their study on the Egyptian woods, such as Bombax tree (Bombax malabricum), Entreolobium (Entreolobium timbora) and Emeri tree (Terminalia arjume), they found that, these wood species are considered the most favorable for subterranean termite A. desertorum. Badawi et al.,1984, tested the five local wood species in Saudi Arabia as follows: Athel (Tamarix aphylla), Sidir (Zizyphus spina-christi), Hamat (Ficus pseudosycamorus), Talh (Acacia etbaica) and Arar (Juniperus procera) for their susceptibility of subterranean termite infestation. The wood species Arar (Juniperus procera) classified moderately durable, while the wood species Hamat (Ficus pseudosycamorus) was heavly infested with subterranean termite and showed the highest damage ratings. The other wood species exhibited varying degrees of subterranean termite infestation.

\subsubsection{Imported wood species}

Data in Table (2) show that, the wood of Beech (Fagus sp.) was the most susceptible to subterranean termite $P$. hybostoma infestation of the tested wooden stakes followed by Erupean spruce (Picea sp.), while the wood of Mirbeck oak (Quercus mirbekii Dur.) was the least susceptible to insect infestation. Mahogany (Khaya sp.) and Swedish pine (Pinus sp.) showed durable resistance to the subterranean termite $P$. hybostoma infestation. The mean numbers of the previous mentioned wood species were significantly different being $3.67,2.33,1.67,0.33$ and 0.00 (stakes per 30 stakes) for Beech, European spruce, Mirbeck oak, Swedish pine and 


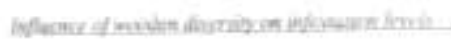

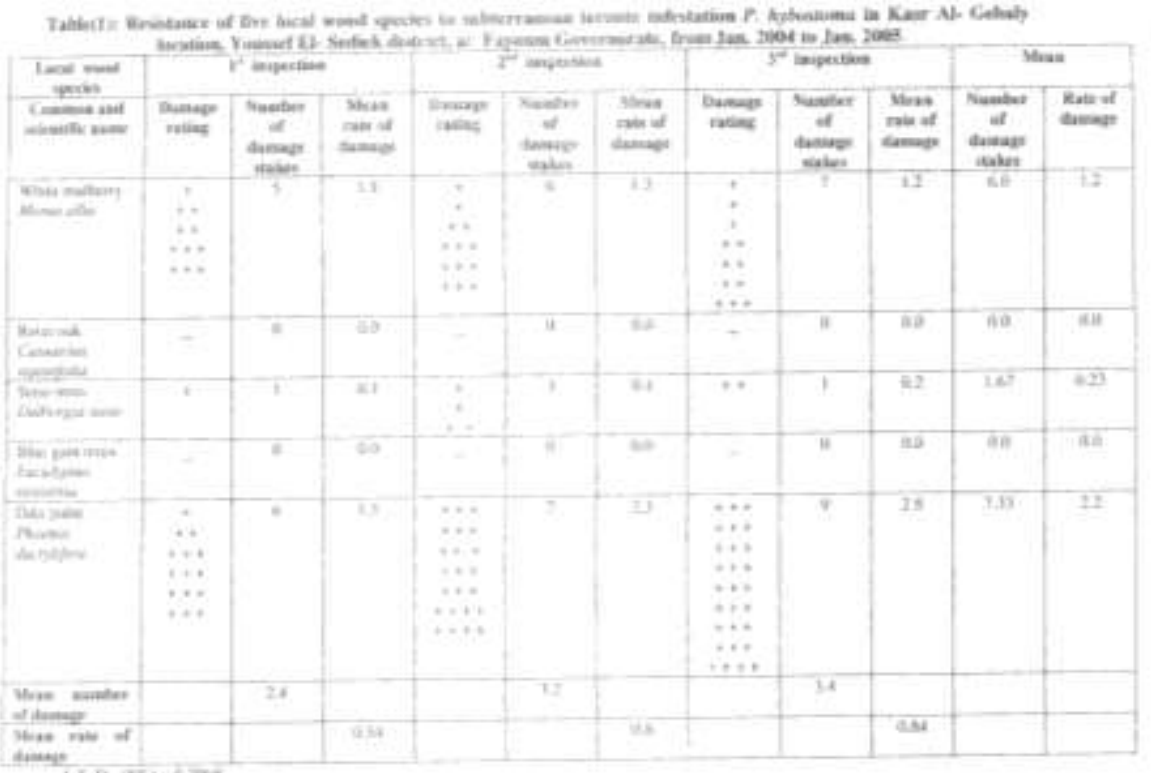

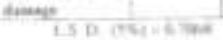

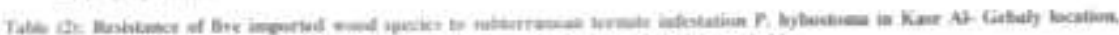

\begin{tabular}{|c|c|c|c|c|c|c|c|c|c|c|c|}
\hline \multirow{2}{*}{ 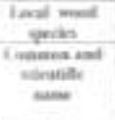 } & \multicolumn{3}{|c|}{ r inipuatis } & \multicolumn{3}{|c|}{$I^{\prime}$ asperiten } & \multicolumn{3}{|c|}{$y^{\prime}$ inquilin } & \multicolumn{2}{|c|}{ Men: } \\
\hline & $\begin{array}{l}\text { Truesyr } \\
\text { now }\end{array}$ & on & $\begin{array}{l}\text { Shias } \\
\text { nated } \\
\text { seas }\end{array}$ & $\begin{array}{l}\text { linesy } \\
\text { chest }\end{array}$ & 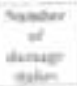 & 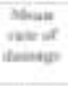 & 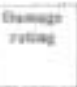 & 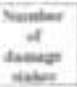 & 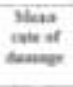 & 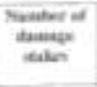 & 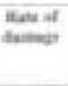 \\
\hline 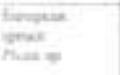 & $=$ & +9 & int & $\because \cdots$ & y & in & $\begin{array}{l}\ldots * \\
\cdots \cdots \\
\cdots+1\end{array}$ & 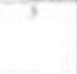 & 6.7 & $2 n$ & 25 \\
\hline 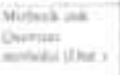 & - & ii & ae & ; & 2 & in & $m$ & 5 & 10.7 & Iथा & a) \\
\hline fown & $\therefore$ & 7 & atis & $\cdots \cdots$ & 3 & 11 & $\begin{array}{l}\ldots * \\
\ldots \cdots \\
\cdots \cdots \\
\cdots \cdots\end{array}$ & 3 & 22 & In: & 3 \\
\hline lank & $=$ & F & "1ii & - & * & $\overline{10}$ & $*$ & 1 & air & a.1. & 90 \\
\hline 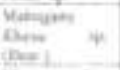 & - & it & 70 & $=$ & 4 & nin & - & 8 & $a n$ & inis & 200 \\
\hline Whas newter & & aif & & & is & & & 24 & & & \\
\hline Whas not of & & & oif & & & ats & & & in & & \\
\hline
\end{tabular}

ing nom 
Mahogany, respectively. The corresponding rates of damage of these wood species were 1.3, 0.73, $0.3,0.03$ and 0.00 , respectively. These results revealed that, the wood of Mahogany (Khaya sp.), was highly resistance to the subterranean termite $P$. hybostoma, where, no record of any infested wood stakes during the three inspections, followed by Swedish pine ( Pinus sp.) (Considered relatively resistance) where, only one wooden stake was infested during the three inspections. The wood of Beech (Fagus sp.) and Erupean spruce (Picea sp.) were perishable. Tested wood species could be arranged according to their resistance to the subterranean termite $P$. hybostoma infestation as follows: Mahogany (Khaya sp.), Swedish pine ( Pinus sp.), Mirbeck oak (Quercus mirbekii Dur.), Eurpean spruce (Picea sp.) and Beech (Fagus sp.), respectively. These results are in agreement with those of Badawi et al.,1984. They found that, the wood of Mahogany (Khaya sp.) was characterized by durable resistance to subterranean termite $P$. hybostoma, while, the wood of Beech (Fagus sp.) was heavy infested with the same species of termite and showed the highest damage and ratings. The other wood species spruce (Picea sp.) , pine ( Pinus sp.) and Apitong (Dipterocarpus sp.) exhibited varying degrees of subterranean termite infestation. Beal et al.,1982, tested 92 American woods species by using the host selection and force feeding methods. These wood species were arranged into five resistance categories according to the percentage of wood consumption by workers of $P$. hybostoma. They mentioned that, workers survived 6 weeks on 11 wood species from 92 wood species within 81 resistance woods ( $1^{\text {st }}$ group) and survived 6 weeks on 5 wood species. Creffield et al., (1985), showed that, the wood of Pinus radiata was more resistant to attack by subterranean termite Coptotermes acinaciformis than Eucalyptus regnans. This termite species caused a mean percentage consumption of $58.26 \%$ in Eucalyptus against $50.66 \%$ in pine. The pine wood seemed to be more susceptible to attack by subterranean termite than Eucalyptus wood. Grace and Yamamoto (1994), mentioned that, the wood of red wood (Sequoia sempervirens) has a fairly high durability in short term exposures to high termite activity, while, the wood of, Alaska yellow cedar (Chamaecyparis nootkatensis) was considerably more durable than red wood. The wood of Laotian teak (Tectona grandis) was considerably resistant to subterranean termite attack, its resilience in field tests. Grace et al.,(1998), showed that, subterranean termite colonies feed on Pecan, (Carya illinoensis) and red gum (Liquidambar styraciflua). These wood species were highly preferred by subterranean termite Coptotermes formosans Shiraki. Regina et al. (2004), found that, the wood consumption rates were not correlated significantly with their wood densities, there was a tendency of the soft woods (Eucalyptus robusta and Pinus sp.) to be more consumed by subterranean termites than the woods of intermediate hardness (E. pellita and $E$. urophylla). Among the Eucalyptus, (E. robusta), showed to be more susceptible to attack by subterranean termites than (E. pellita and $E$. urophylla), indicating that, the former is more susceptible to termite attack.

\section{REFERENCES}

Abreu R.L.S. and Silva K.E.S. (2000). Resistencia natural de dez especies madereiras da Amazonia ao ataque de Nasutitermes macrocephalus(Silvestre) e N. surinamensis (Holmgren) (Isoptera:Termitidae) Revista Arvore, 24: 229-234.

Ahmed H. M. (1997). Ecological studies and Control of Harvester Subterranean Termite Anacanthotermes ochraceus (Burmeister) at Fayoum Governorate. M. Sc. Thesis pp. 77

Badawi A, Faragalla A .A. and Dabour A. (1984).The natural resistance of some imported wood species to subterranean termites in Saudi Arabia. Z.ang. Entom. 98(5): 500- 504.

Badawi A, Faragalla A .A. and Dabour A. (1985). The relative protective effectiveness of some wood preservatives in ground contact against subterranean termites in central region of Saudi Arabia. Intern. Pest. Control, (Nov./ Dec . 1985): 150 -151.

Beal R. H., Carter F .L. and Southwell C.R. (1974). Survival and feeding of subterranean termites on tropical woods. Forest products Journal. 24(6):44-48.

Beal R. H. (1979). Particle board, hardboard and plywood adhesive. Forest Products Journal. 29 (12): 29-34.

Beal R. H, Rizk M.M.and Maher A.A. (1982). The susceptibility of certain American woods to Psammotermes hybostoma (Deseneux) in the New Valley of Egypt. Assiut J. of Agric. Sci. 13 (3): 117-130. 
Bultman J. D, Beal R.H. and Ampong F.F.K. (1979). Natural resistance of some tropical African woods to Coptotermes formosanus (Shiraki) Forest Products Journal. 29 ( 6): 4651.

Creffield J. W., Howick C. D. and Pahl P.J. (1985).Comparative wood consumption within and between mounds of Coptotermes acinaciformes

(Froggatt)

(Isoptera:Rhinotermitidae). Sociobiology, 7: 77-86

Delate K.M. and Grace J.K.(1995). Susceptibility of neem to attack by the Formosan subterranean termite, Coptotermes formosanus Shiraki Isoptera:Rhinotermitidae).J.Appl.Entomology,119: 93-95.

Grace J.K.and Yamamoto R.T. (1994).Natural resistance of Alaska-cedar, red wood, and teak to Formosan subterranean termites Forest Products Journal 44(3): 41-45.
Grace J.K., Ewart D.M.and Tome C.H.M. (1998). Termite resistance of wood species grown in Hawaii. Shiroari 111: 32-34

Haverty M. I. and Nutting W. L. (1975). Natural wood preferences of desert termites. Ann. Entomol. Soc.Am.68: 533-536.

Rizk M.M., Khalil F. M, Ali A. W. M, AbouGhadir M.F.and Abdel- hafez N.A. (1982).Survival and feeding activity of Amitermes desertorum (Deseneux) on the Egyptian timbers. Assiut J. of Agric. Sci. 13 (3): 131-135.

Regina C.P., Euripedes B.M. and Acacio G.C. (2004).Wood consumption rates of forest species by subterranean termites (Isoptera) under field conditions. Revista Arvore, 24: 225-232.

\footnotetext{
تأثير التنوع الخثبى على مستويات الإصابة بالنمل الابيض تحت الأرضى Psammotermes hybostoma (Deseneux)

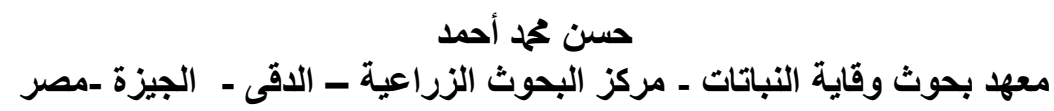

ملخص

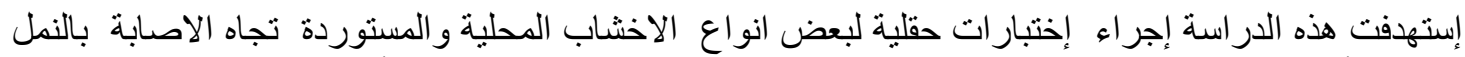

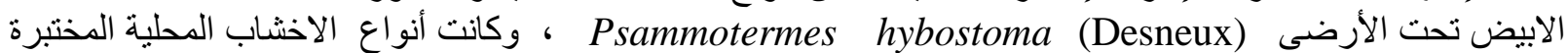

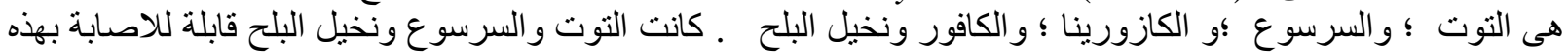

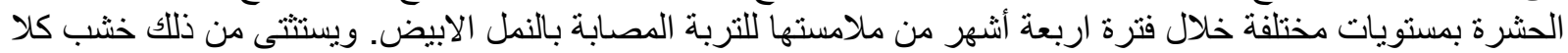

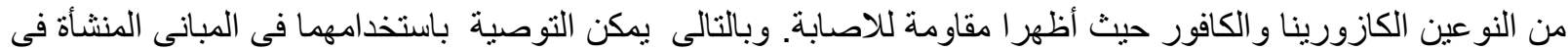

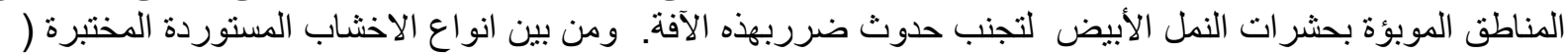

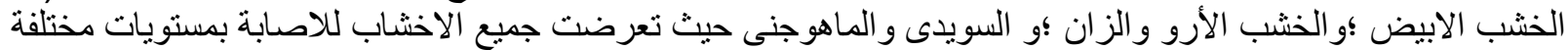

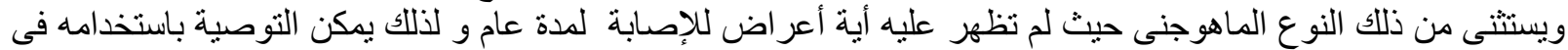

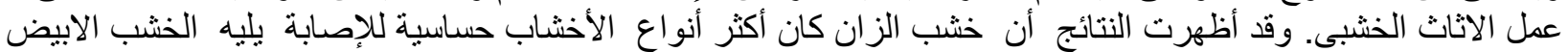

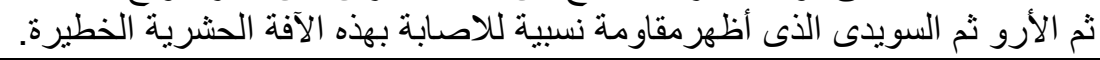

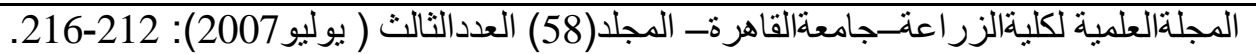

